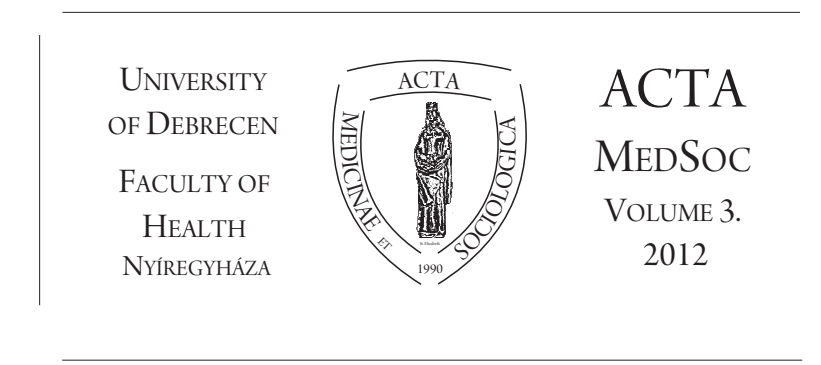

\title{
Korunk válsága és feladataink
}

\section{Berényi Dénes †}

\author{
akadémikus
}

\begin{abstract}
The crisis of our age.
When discussing the present world economic crisis not only do we ask whether it exists but rather how large it is. Even scientists examining and taking a closer look at the nature of the crises do not necessarily share the same opinion on the essence of the crisis; what mechanism triggered and strengthened it, what impact it might have, and most important of all what could be done against it. The study introduces the two most important interpretation frames: a crisis generated by the global capital and a crisis generated by the modern people's disillusion.
\end{abstract}

Keywords: economic crisis, global capital mechanism, modern peolple's disillusion DOI: $10.19055 / \mathrm{ams} .2012 .3 / 4-5 / 1$

Ma már közhelynek számít, hogy korunk, társadalmunk különbözô válságok között ốlődik: válságban van a gazdaság, az ipar, a nyersanyagellátás, az erkölcs, a társadalom és az individuum, stb., stb. Talán azt lenne hirtelen nehéz megmondani, hogy az élet melyik területe nincs ma válságban.

Mindennek hatalmas irodalma van. Legalábbis az elsók között volt ezen a területen a Római Klub jelentése „A növekedés határai”-ról szól (Meadows et al. 1972), amely rámutatott a Föld véges eróforrásaira. Ezt követték további jelentései és tôle függetlenül szinte megszámlálhatatlan további kiadványa a „válságirodalomnak", amelyek különböző szempontokból közelítik meg a kérdést. Csak példaképpen említek meg néhányat. Egyike a legismertebbeknek Korten (1996) könyve „A tókés táraságok világuralmáról”. A hatalmas „választékban” vannak azután a talán kevésbé radikálisok (Giddens 2000; George 2009) és radikálisabbak (Martin és Schumann 1998) és - ha egyáltalán lehet így osztályozni ezeket a múveket -, köztük 
talán a „legvégsőbbekig” elmenő Viviane Forrester (1998) „Gazdasági horror” címú könyve. Itt kell megemlítenünk Huntington (1998) széles körben nagy port felkavart múvét is. Még hosszan lehetne folytatni a felsorolást. Érdekes módon még Soros György (1999) is beállt ebbe a sorba.

Nézzük hát meg, hogy mirôl is van tulajdonképpen szó, kiindulásképpen vegyük a világ megosztottságát. „... a többségi világ lakosai naponta 30 millió dollárt fizetnek a gazdag országoknak adósságtörlesztés címén, miközben több millió állampolgáruk a legnagyobb nyomorban él." „„.. arra kényszerítik az adósokat, hogy olyan szociális programokra szánt közkiadásokat csökkentsenek, mint az oktatás, az egészségügy és a foglalkoztatás, mert az ilyen megszorítások elsôsorban a szegényeket sújtják.” „Minden évben dollár milliárdokat költenek bonyolult biotechnológiai kutatásokra, hogy ritka genetikai rendellenességeket azonosíthassanak és gyógyítsanak, hogy kutatásokat végezzenek a génterápia és az ôssejt alkalmazásának területén, valamint az öregedési folyamat lelassítása érdekében. Ugyanakkor a szegény országokban gyermekek százezrei halnak meg olyan betegségekben, amelyek minimális orvosi technológiával könnyen kezelhetók lennének. Gyermekek vakulnak meg örökre néhány centet érô A-vitamin híján." - írta John Stott abban a könyvében, amelyik 2009-ben magyarul is megjelent (Stott 2009).

Ehhez hasonlóan fogalmaz Jean Ziegler (2009), aki kétségtelenül a legradikálisabbak közé tartozik a szóban forgó körben. Könyve bevezetőjében nem rejti véka alá: „Szándékom, hogy könyvem fegyverül szolgáljon ... a harcban.” Nem csoda, hogy harcra buzdít, hiszen a könyv tényszerú megállapításai tényleg megdöbbentőek. „,.. az adósság és az éhség az a két tömegpusztító fegyver, amelyet a világ urai arra használnak, hogy szolgálatukba állítsák a népeket, azok munkaerejét, nyersanyagait ..." De kik a világ urai? 2006-ban „... az 500 legerôsebb transzkontinentális magánvállalat ellenôrizte a bruttó világtermelés, azaz a Földön egy év alatt megtermelt összes javak ... több mint 52\%-át.” „Ez az ötszáz vállalat több értéket tart ellenôrzése alatt, mint a világ 133 legszegényebb országának összes vagyona.” „A rablókapitalizmus létrehozta gazdasági, társadalmi és politikai világrend azonban nem csak gyilkos: abszurd is.” „Az adósságszolgálat (tőke-plusz kamattörlesztés) az eladósodott ország erőforrásainak nagy részét felemészti. Utána már semmi sem marad a szociális beruházásokra: a közoktatásra, a közkórházakra, a társadalombiztosításra stb.” „Amikor fenyeget a fizetésképtelenség, ... megjelennek Washingtonból az IMF fogdmegjei. Kivizsgálják az ország gazdasági helyzetét, megírják a letter of intentet (szándéklevelet). A fojtogatott országnak 'önként' kell elfogadnia egy újabb csavarást.” Majd késóbb ezt írja: „Ha van olyan kifejezés, amelytől mindig viszolyogtam az a 'piacok bizalma' ”. Egyébként ,... az új feudális urak kontrollálási eszköze a korrupció”. Hiszen „A miniszterek, bírák, a funkcionáriusok, a regionális és helyi politikusok rosszul vannak fizetve", tehát könnyen megvesztegethetôk. Egyébként a svájci nemzetiségú Ziegler 2000-tôl évekig volt az ENSZ élelmezésjogi raportôre, és járta a harmadik világ országait. Így jól ismeri ezeknek az országoknak a helyzetét nem csak könyvekból és statisztikai adatok alapján, de saját személyes tapasztalataiból is. 
Ide kívánkoznak még a francia ellenállás veteránjának, a Buchenwaldot megjárt, kilencvennégy éves Stéphane Hessel (2011) éppen most megjelent kiáltványából a következő sorok. Hessel egyébként az ENSZ Emberi jogok nyilatkozatának egyik megszövegezóje volt 1948-ban.

„Azt merészelik mondani nekünk, hogy az állam nem képes többé biztosítani a szociális juttatások költségeit. De miként lehetséges az, hogy ma nincs pénz ezeknek a vívmányoknak a fenntartására és kiterjesztésére, holott a termelés a felszabadítás ${ }^{1}$ óta, amikor is Európa romokban hevert, jelentős mértékben növekedett? Csakis azért, mert a pénz hatalma ... még sohasem volt ilyen nagy, ilyen arcátlan és önzô, és a kiszolgálói még sohasem hatoltak be ennyire a legfelsóbb állami szférákba."

Egészen más oldalról közelíti meg a válságot Christa Meves (2009), aki szerint a válság okainak a mélyére kell hatolni. A mai kor embere hajszolja a vagyont, az élvezetet, végülis ,... megunjuk az élvezetet, megcsömörlünk tóle, elegünk lesz belőle és mást, jobbat, újabbat kívánunk. A régiek ezt nagyon jól tudták, nagy bölcsességi könyvek, mindenek előtt a Biblia, de az I. King és a Korán le is írták, és még a népmesék szerint sem teszi boldoggá az embert, ha mindene a legbooségesebben megvan életében." Számos téveszmével nem merünk szembenézni: a pénz uralma, a hatalom hajhászása, a profit és az élvezetek mindenek fölé helyezése, a fogyasztás istenítése, a „bưn”, mint olyan, továbbá a halállal szembenézés kiiktatása az egyén és a társadalom életéból, végül az önzés és individualizmus szélsôséges ideológiái. A kapitalizmus számos rombolásának, a modern kizsákmányolásnak a mélyén is ezek az okok húzódnak meg.

Az embernek végülis el kell gondolkodnia azon, amit Christa Meves ajánl - aki mint pszichológus, valamint gyermek- és ifjúsági terapeuta naponta észleli a válság tüneteit -, hogy nem kellene-e függetleníteni magunkat a korszellemtől, illetve megfelelő kritikával végiggondolni, hogy mi a tényleges igazságtartalma annak, amit a korszellem kényszerítően sugall. Arra vonatkozólag, hogy a korszellem mennyire rányomhatja a bélyegét a társadalomra, de még a tudományra is, - a számos példa közül - hadd hivatkozzunk arra, hogy a XX. század elején az eugenika és a rasszizmus nem valamiféle elmaradt, reakciós ideológiának számított, hanem a tudomány élvonalához tartozott és a társadalomban pedig ,... olyan lelkesen fogadták, mint az emberek által gerjesztett globális felmelegedés elméletét manapság." - írja napjaink kiemelkedő történésze, Niall Ferguson (2011). A nácizmus és a holokauszt megrázkódtatása kellett ahhoz, hogy mindez megváltozzon.

Slavoj Žižeknek, korunk egyik jelentôs gondolkodójának álláspontja közel áll Meveséhez. Az elóbbiekben már idézett Hesselhez képest más alapokról kiindulva jut hasonló következtetésre. „Itt az ideje - írja 2010-es kiáltványában -, hogy az erkölcsre, az igazságra, a fenntarthatóságra való törekvés kerekedjen felül, mivel igen komoly veszélyek fenyegetnek bennünket. Olyan veszélyek, amelyek véget vethetnek az emberi kalandnak egy olyan bolygón, amely lakhatatlanná válik számunkra." Mindezeken annál inkább el kell gondolkozni, mert legtöbben csak a bajokat tárják fel, de a megoldásra nincs javaslatuk (Žižek 2010)

\footnotetext{
${ }^{1}$ t.i. Európa felszabadítása, a II. Világháború vége óta.
} 
A fentiek azonban nem jelenthetnek valamilyen nosztalgikus múltba nézést, hanem jelentik azt a kritikai szemléletet, amely szerves része a tudományos gondolkodásnak. A tudományos gondolkodást az jellemzi legjobban, hogy kritikával illeti saját megállapításait, eredményeit is. Valójában arról van szó, hogy a mai divatos „,korszerû” állításokat antropológiai, szociológiai, pszichológiai és i.t. vizsgálatok tárgyává kell tenni, hogy érvényességüket, ill. érvényességük mértékét megbízhatóan megállapíthassuk nem befolyásoltatva attól, hogy a korszellemmel megegyezó vagy attól eltéró eredményre jutunk.

\section{Irodalomjegyzék}

Ferguson, N. (2011): Civilizáció - A Nyugat és a többiek. Scolar Kiadó, Budapest. Forrester, V. (1998): Gazdasági horror. Kossuth Kiadó, Budapest.

George, S. (2009): Lugánói tanulmány. Kairosz Kiadó, Budapest.

Giddens, A. (2000): Elszabadult Világ. Perfekt Kiadó, Budapest.

Hessel, S. (2011): Háborodjatok fel! Scolar Kiadó, Budapest.

Huntington, P. S.: (1998): A civilizációk összecsapása és a világrend átalakulása.

Európa Kiadó, Budapest.

Korten, C. D. (1996): Tókés társaságok világuralma. Kapu Kiadó, Budapest.

Martin, H-P.; Schumann, H. (1998): A globalizáció csapdája. Perfekt Kiadó, Budapest.

Meadows, D.; Meadows, D.; Randers, J.; Behrens, W. W. (1972): The Limits to Growth. New American Library. New York.

Meves, C. (2009): Manipulált mértéktelenség. Kairosz Kiadó, Budapest.

Soros György (1999): A globális kapitalizmus válsága. Scolar Kiadó, Budapest.

Stott, J. (2009): Korunk égető kérdései. Harmat Kiadó, Budapest.

Ziegler, J (2009): A szégyen birodalma. Kairosz Kiadó, Budapest.

Žižek S. (2010): Living in the End Times. Verso, London.

Prof. Dr. Berényi Dénes atomfizikus, akadémikus, nyugalmazott egyetemi tanár 